\title{
Use of Clinical Cases in a Virtual Learning Environment as an Approach to Teaching Human Embryology
}

\author{
Uso de Casos Clínicos en Ambiente Virtual como \\ Estrategia de Enseñanza de la Embriología Humana
}

${ }^{*}$ Fernanda Ginani; **Rodrigo Gadelha Vasconcelos\& ${ }^{* * *}$ Carlos Augusto Galvão Barboza

GINANI, F.; GADELHA V. R.; \& GALVÃO B. C.A. Use of clinical cases in a virtual learning environment as an approach to teaching Human Embryology. Int. J. Morphol., 30(4):1395-1398, 2012.

SUMMARY: The objective of this study was to evaluate the effectiveness of virtual learning as an approach to teaching human embryology. For this purpose, clinical cases comprising the six major topics of human embryology were organized into a blog in order to complement the content discussed in the classroom. Scientific articles were made available to reinforce theoretical contents and ethical-humanistic issues were addressed in discussion forums. The mean grades of the students at the end of the semester were compared with those of the previous semester when the method had not been applied. Student perceptions of blog effectiveness were evaluated using an electronic questionnaire. A substantial increase in mean grades was observed compared to the previous class. Analysis of the questionnaires showed that the students considered the blog to be a practical and useful learning tool. In conclusion, the use of clinical cases in a virtual learning environment is an effective tool to teach human embryology.

KEY WORDS: Teaching; Medical education; Embryology; Blog.

\section{INTRODUCTION}

Embryology has become an important research area over the last few years because it encompasses topics of major interest, such as artificial reproduction, embryo manipulation, tissue engineering, and stem cells. The rapid sequential and three-dimensional changes that occur simultaneously at the macroscopic and microscopic level make the processes of prenatal development difficult to understand (Yamada et al., 2006). However, the study of these processes is fundamental to provide medical students with a consistent scientific basis that helps them understand the mechanisms involved in normal and abnormal human development, as well as in the clinical and surgical treatment of malformations (Moraes \& Pereira, 2010).

The approaches used to teach human embryology include wax embryo models, clinical case studies of malformations, images, and videos, among others (Carlson, 2002; Puerta-Fonolla et al., 2004; Yamada et al.). In this respect, the use of digital resources combined with the facilities provided by the internet pave the way for new teaching methods in this area.
An educational approach based on online teaching combines important features that contribute to improve the quality of teaching since it favors distance learning, as well as the use of images of histological sections prepared by special techniques that are normally not available for undergraduate teaching. The introduction of new technologies raises in the student the interest in continuous improvement since many of these methods permit the generation of knowledge based on a transdisciplinary approach (Ferreira \& Kempinas, 2008).

The objective of the present study was to evaluate the adherence to and effectiveness of a teaching method in human embryology using a blog of clinical cases among students enrolled in the medicine course of the Federal University of Rio Grande de Norte (UFRN).

\section{MATERIAL AND METHOD}

As a complementary strategy for teaching the curriculum content of embryology, a digital tool (blog) was created using the six major topics of human embryology:

* Masters Candidate, Department of Morphology, Federal University of Rio Grande do Norte, Brazil.

** PhD Candidate, Department of Morphology, Federal University of Rio Grande do Norte, Brazil.

**** Associate Professor, Department of Morphology, Federal University of Rio Grande do Norte, Brazil. 
fertilization and segmentation; blastocyst implantation and twinning; gastrulation and production of cell diversity; neurulation and folding of the embryo; human congenital defects, and stem cells. These topics were selected in order to follow the sequence of prenatal development and comprised the main morphophysiological events of embryology.

Six clinical cases comprising all topics proposed were selected. Literature reviews on the cases selected were also made available in the blog to reinforce the theoretical contents studied. Ethical-humanistic issues across all topics were discussed transversely in electronic discussion forums.

After the embryology classes, the knowledge of the students was evaluated using a traditional method and the mean grades were compared to those of the previous semester when the method had not been applied. Statistical analysis of the data was performed by the Student t-test, adopting a level of significance of $5 \%$.

A questionnaire consisting of 17 items to be answered voluntarily and anonymously was sent to the participants through the SurveyMonkey site in order to evaluate effectiveness of the blog for learning. Thirty-five of the 45 students enrolled participated in the study. The questions were divided into three parts: access of the students to the teaching material, effectiveness of the teaching method, and content evaluation.

\section{RESULTS}

Comparison of mean grades between students who had access to the blog and those who did not revealed substantially higher grades in the former (Fig.1).

Analysis of the questionnaires showed that most students $(54.3 \%)$ accessed the blog sporadically, whereas the remaining students (45.7\%) accessed the blog throughout the course. All students considered access to the blog to be simple and $77.1 \%$ classified the contribution of this tool to embryology teaching as very significant. The student perceptions of the effectiveness of the method are summarized in Table I.

As reported by the students, the electronic discussion forums served as an informal environment, facilitating the exchange of ideas and clarification of doubts. Most students $(91.2 \%)$ also reported that the contents made available in the clinical case blog were adequately explored in the content evaluation.

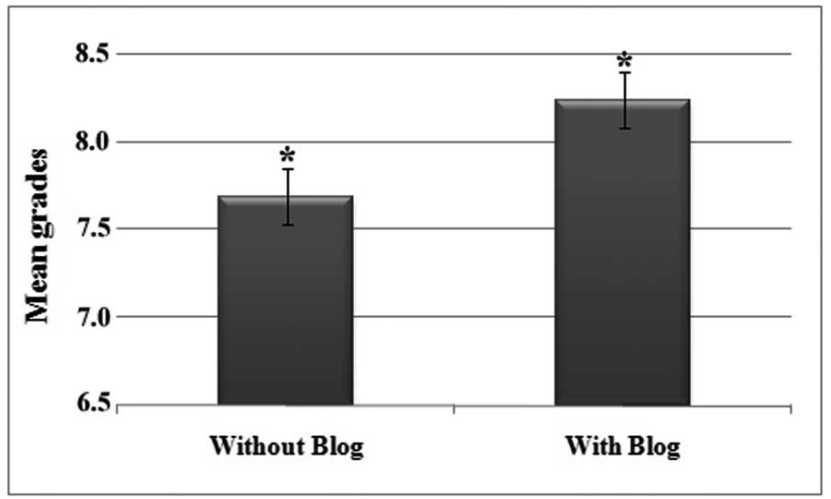

Fig. 1. Mean grades of the students. ${ }^{*} \mathrm{p}=0.0182$ (Student t-test).

Table I. Student perception of blog effectiveness (Brazil, 2011)

\begin{tabular}{lccc}
\hline & Yes & No & Indifferent \\
\hline $\begin{array}{l}\text { Facilitates learning } \\
\begin{array}{l}\text { Increases the interest in } \\
\text { embryology }\end{array}\end{array}$ & 97.1 & 0 & 2.9 \\
$\begin{array}{l}\text { Permits interaction with the } \\
\text { team }\end{array}$ & 60 & 8.6 & 31.4 \\
$\begin{array}{l}\text { Broadens content } \\
\text { Favors clinical application }\end{array}$ & 94.3 & 2.9 & 2.9 \\
$\begin{array}{l}\text { Encourages the search for } \\
\text { complementary mate rial }\end{array}$ & 40 & 37.1 & 22.9 \\
$\begin{array}{l}\text { Improves fixation of the } \\
\text { content }\end{array}$ & 94.3 & 0 & 5.7 \\
$\begin{array}{l}\text { Discussion of clinical cases } \\
\text { is important }\end{array}$ & 85.7 & 8.6 & 5.7 \\
$\begin{array}{l}\text { Comprises ethical and } \\
\text { humanistic issues }\end{array}$ & 94.3 & 5.7 & $\mathrm{NE}$ \\
$\begin{array}{l}\text { Permits interdisciplinarity } \\
\begin{array}{l}\text { Encourages scientific } \\
\text { initiation }\end{array}\end{array}$ & 74.3 & 25.7 & $\mathrm{NE}$ \\
\hline
\end{tabular}

Values are reported as percentage. NE: not evaluated.

\section{DISCUSSION}

E-learning is defined as the use of internet technologies to increase knowledge and performance and can be used by medical educators to improve the efficiency and effectiveness of educational interventions in response to social, scientific and educational challenges (Ruiz et al., 2006). The application of e-learning varies widely among medical schools and seems to be more common in the area of basic sciences than in clinical disciplines (Ward et al., 2001). 
Cabral \& Barbosa (2005) observed that students who had access to digital educational resources to facilitate the study of anatomy better understood the objectives of the class. In addition, the students considered this resource to be an important auxiliary learning tool which, however, does not replace practical laboratory classes. Accordingly, Prieto et al., (2011) believe that the use of blogs as a teaching tool does not replace the work of students with the teacher in the classroom but represents a significant support for learning. Pilcher (2001) evaluated a new type of course in which complementary material was made available online to dentistry students in addition to the traditional class. The author observed that the approach was effective and that the feedback of the students contributed to improve this new method, in agreement with the present findings.

Eynon et al., (2003) evaluated the use of the World Wide Web (WWW) as an approach to teaching health in a group of undergraduate students. The main potential advantages were convenience, availability of information, and the ability to reinforce or recover aspects of the didactic module that the students did not understand or had lost. These results agree with the present findings demonstrating a better utilization of the content taught. Thus, teaching strategies supported by web information and communication tools are possible approaches that need to be explored since the introduction of digital technologies has the potential to promote significant changes in educational models.

The method proposed in the present study based on the online teaching of the basic processes of development using clinical cases combines important features that contribute to improve the quality of teaching since it favors distance learning and improves basic skills in health courses.
In addition, transdisciplinary and ethical-humanistic contents are better addressed, items that often cannot be taught satisfactorily in the classroom because of timetable limitations (Ferreira \& Kempinas).

The present findings, supported by the results of recent studies (Maia \& Struchiner, 2010; Ramos \& Struchiner, 2011), demonstrate a better academic performance of those students who accessed the blog since it permitted the use of clinical cases and a consequent better fixation of the content administered. Thus, the use of case studies in medical teaching is fundamental and contributes to the adequate organization of information by the student, which will be necessary to apply clinical reasoning in practical situations (Sé et al., 2008).

In this respect, digital resources are becoming an important part of health education (Schultze-Mosgau et al., 2004; Beux \& Fieschi, 2007; Chen et al., 2008; Turmezei, 2009; Silva et al., 2011). It is therefore expected that the inclusion of these resources in the study of morphological sciences will facilitate access to practical contents involved in distance learning in order to extend the benefits to different education sectors of the society.

The present study showed that the use of a blog of clinical cases permitted the interdisciplinary and transdisciplinary integration of contents, encouraged the reading of complementary material, and improved the learning of transverse contents related to human embryology. It can be concluded that this method is an effective tool for teaching human embryology. The present study is expected to contribute to the dissemination of virtual learning environments as auxiliary teaching tools in the area of morphological sciences.

GINANI, F.; GADELHA V. R.; \& GALVÃO B. C. A. Uso de casos clínicos en ambiente virtual como estrategia de enseñanza de la Embriología Humana. Int. J. Morphol., 30(4):1395-1399, 2012.

RESUMEN: El objetivo del trabajo fue evaluar la eficacia de un método de enseñanza de la Embriología en ambiente virtual. Para complementar el contenido discutido en clases, fueron organizados en un blog, casos clínicos abordando seis ejes temáticos de Embriología Humana. Artículos científicos estuvieron disponibles para consolidación de los contenidos teóricos y el eje ético-humanístico fue abordado en foros de discusión. Al final del semestre la media de las notas de los alumnos fue comparada con la media de un semestre anterior donde la metodología no fue utilizada. La percepción de los alumnos con relación a la eficacia del uso del blog en el aprendizaje fue evaluada a través de un cuestionario electrónico. Se observó aumento considerable de la media de las notas al ser comparadas con las notas del período lectivo anterior. El análisis de los cuestionarios reveló que los alumnos consideraron el blog como un instrumento práctico y útil de aprendizaje. Se concluye que esta metodología representó una herramienta eficiente em la enseñanza de los contenidos de Embriología Humana.

PALABRAS CLAVE: Enseñanza; Educación Médica; Embriología; Blog.

\section{REFERENCES}


Cabral, E. T. \& Barbosa, J. M. N. Students' opinions on the use of computer rooms for teaching Anatomy. Int. J. Morphol., 23(3):267-70, 2005.

Carlson, B. M. Embryology in the medical curriculum. Anat. Rec., 269(2):89-98, 2002.

Chen, Y. K.; Hsue, S. S.; Lin, D. C.; Wang, W. C.; Chen, J. Y.; Lin, C. C. \& Lin, L. M. An application of virtual microscopy in the teaching of an oral and maxillofacial pathology laboratory course. Oral Surg. Oral Med. Oral Pathol. Oral Radiol. Endod., 105(3):342-7, 2008

Eynon, R.; Perryer, G. \& Walmsley, A. D. Dental undergraduate expectations and opinions of Web-based courseware to supplement traditional teaching methods. Eur. J. Dent. Educ., 7(3):103-10, 2003.

Ferreira A. S. S. B. S. \& Kempinas, W. G. Ambiente virtual para o ensino/aprendizagem de Embriologia. May 2008. Available on: <http://www.abed.org.br/congresso2008/tc/617200841 555PM.pdf>. Accessed in: July 7th. 2011.

Maia, F. \& Struchiner, M. The use of weblogs and orkut communities as pedagogical tools in courses in the health area. Interface - Comunc., Saude, Educ., 14(35):905-18, 2010.

Moraes, S. G. \& Pereira, L. A. V. A multimedia approach for teaching human embryology: Development and evaluation of a methodology. Ann. Anatomy, 192(6):388-95, 2010.

Pilcher, E. S. Students' evaluation of online course materials in fixed prosthodontics: a case study. Eur. J. Dent. Educ., 5(2):539,2001

Prieto, R.; Smok, C. \& Rojas, M. Experiencias de Blog: Placenta Comparada. Int. J. Morphol., 29(2):432-5, 2011.

Puerta-Fonollá, J.; Vázquez-Osorio, T.; Ruiz-Cabello, J.; MurilloGonzález, J. \& Peña-Melián, A. Magnetic resonance microscopy versus light microscopy in human embryology teaching. Clin. Anat., 17(5):429-35, 2004.

Ramos, P. \& Struchiner, M. Development of a virtual environment for medical education by a multidisciplinary team: factors that influence the analysis on the educational problem. InterfaceComunic., Saude, Educ., 15(36):227-42, 2011.

Ruiz, J. G.; Mintzer, M. J. \& Leipzig, R. M. The impact of Elearning in medical education. Acad. Med., 81(3):207-12, 2006.

Schultze-Mosgau, S.; Zielinski, T. \& Lochner, J. Web-based, virtual course units as a didactic concept for medical teaching. Med. Teach., 26(4):336-42, 2004.

Sé, A. B.; Passos, R. M.; Ono, A. H. \& Hermes-Lima, M.. The use of multiple tools for teaching medical biochemistry. $A d v$. Physiol. Educ., 32(1):38-46, 2008.
Silva, C. S.; Souza, M. B.; Silva-Filho, R. S.; de Medeiros, L. M. \& Criado, P. R. E-learning program for medical students in dermatology. Clinics, 66(4):619-22, 2011.

Turmezei, T. D.; Tam, M. D. \& Loughna, S. A survey of medical students on the impact of a new digital imaging library in the dissection room. Clin. Anat., 22(6):761-9, 2009.

Ward, J. P.; Gordon, J.; Field, M. J. \& Lehmann, H. P. Communication and information technology in medical education. Lancet, 357(9258):792-96, 2001.

Yamada, S.; Uwabe, C.; Nakatsu-Komatsu, T.; Minekura, Y.; Iwakura, M.; Motoki, T.; Nishimiya, K.; Iiyama, M.; Kakusho, K.; Minoh, M.; Mizuta, S.; Matsuda, T.; Matsuda, Y.; Haishi, T.; Kose, K.; Fujii, S. \& Shiota, K. Graphic and movie illustrations of human prenatal development and their application to embryological education based on the human embryo specimens in the Kyoto collection. Dev. Dyn., 235(2):468-77, 2006.

\section{Correspondence to:}

Carlos Augusto Galvão Barboza

Department of Morphology, UFRN

Av Salgado Filho, 3000

Campus Universitário

59072-970

Natal, RN

BRAZIL

Email: cbarboza@cb.ufrn.br

Received: 07-11-2011

Accepted: 28-05-2012 